\title{
Efektifitas Target-Bullying Intervention Program (T-BIP) dalam kasus Bullying di Kabupaten Pangkep
}

\author{
Syahruddin M
}

STAI DDI PANGKEP

udin.yes@gmail.com

\begin{abstract}
Abstrak
Bullying adalah salah satu masalah dalam dunia pendidikan dan sangat umum terjadi pada siswa. Oleh karena itu, banyak sekolah yang mencari solusi dengan menggunakan program intervensi bullying. Penelitian ini menginvestigasi tentang peran T-BIP terhadap pengurangan jumlah perilaku bullying, meningkatkan kesadaran perilaku anti bullying dan melihat persepsi siswa terhadap T-BIP. Secara statistik bahwa T-BIP mengubah perilaku siswa dan mengurangi perilaku bullying meskipun tidak konsisten, tetapi program intervensi ini sangat diterima oleh siswa sehingga menambah pengetahuan siswa tentang bullying dan dampaknya.
\end{abstract}

Kata Kunci: Bullying, T-BIP, Intervensi

\section{Pendahuluan}

Bullying telah menjadi masalah serius dan kerap kali muncul dalam dunia pendidikan. Bullying lebih jauh sering diasosiakan dengan sesuatu yang bersifat negatif dan merusak bagi semua siswa yang terlibat. Oleh karena itu, usaha pencegahan dan intervensi harus dilakukan secara sistematis untuk mengurangi perilaku dan dampak yang ditimbulkan dari perilaku bullying tersebut. Penelitian ini akan menginvestigasi bagaimana program intervensi bullying TBIP (Target Bullying Intervention Program) terhadap menurunnya angka perilaku bullying dan juga bagaimana respon siswa terhadap program T-BIP yang dilakukan di sekolah. Artikel ini dimulai dengan definisi bullying oleh berbagai ahli, dampak bullying yang diakibatkan terhadap pelaku, korban, sekolah dan masyarakat juga digambarkan, sekilas tentang program T-BIP, hasil penelitian dan diskusi, yang ditutup pada bagian akhir sebagai kesimpulan.

Definisi Bullying

Beberapa konsep dan definisi tentang bullying akan dijelaskan dalam bagian ini. Dalam Kamus Oxford English (1991) mendeskripsikan kata kerja "bully" seperti mengganggu secara fisik dan mental, menakut-nakuti, tirani, menindas, menekan dan menggencet. Heinemann menggunakan istilah dan memberi perhatian tentang bullying pada tahun 1973. Dia bekerja di Swedia dan menyebut aktivitas bullying dengan istilah "Mobbing", meminjam istilah dan terjemahan Swedia dalam sebuah buku tentang agresi yang ditulis oleh Konrad Lorenz (1968). Secara harfiah, istilah "Mobbing" bermakna serangan sekumpulan hewan terhadap spesies hewan lain. Lebih rinci disebutkan bahwa, Lorenz menggunakan istilah ini untuk menandakan aksi sekelompok siswa di kelas atau sekelompok tentara melawan seseorang (Olweus, 1994).

Menurut definisi Hukum Inggris, bullying diartikan sebagai kekerasan baik secara fisik maupun psikologis, yang dilakukan oleh seseorang atau kelompok terhadap orang lain dengan secara sadar ingin melukai, mengancam, menakuti dan membuatnya tertekan (Heald, 1994). Konsep dan definisi ini menggabungkan makna dari berbagai aspek dari bullying. Besag (1989) 
mendeskripsikan bullying sebagai sebuah perilaku penyerangan berulang-ulang secara fisik, psikologis, sosial dan verbal bagi yang mempunyai kekuatan dan posisi yang bertujuan menyebabkan stress untuk mencapai tujuannya. Definisi ini lebih menekankan maksud dari pelaku bullying.

Sampai sekarang, belum ada kesepakatan definisi secara umum tentang bullying baik secara psikologis maupun dalam wacana dan kajian pendidikan. Tetapi, kebanyakan peneliti telah menerima definisi bullying yang diutarakan Dan Olweus (1993) yaitu kejadian yang berulang untuk menyakiti orang lain, ketidakseimbangan kekuatan antara pelaku dan korban dan kejadian bullying tidak diprovokasi oleh korban. Bjorkqvist dkk (1992) memberikan dan mengembangkan konsep bullying dengan mengkategorikan bullying menjadi agresi fisik langsung, agresi verbal langsung dan agresi tidak langsung, sosial agresi yang bertujuan merusak hubungan sosial/ persahabatan.

Peneliti yang lain mendefinisikan bullying sebagai perilaku mengganggu, menyakiti secara sengaja baik secara fisik, verbal maupun secara tidak langsung oleh seseorang ataupun sekelompok orang terhadap orang lain, korban umumnya lebih muda, lebih kecil secara fisik, status sosial lebih rendah, dan kurang mendapat dukungan dari teman-temannya (Nanzel, 2001).

Dengan beberapa definisi diatas, kebanyakan peneliti setuju bahwa perilaku bullying memiliki beberapa karakteristik. (1) Pelaku bully bermaksud membebani, menyakiti korban. (2) Agresi terhadap korban terjadi berulang kali dalam kondisi waktu tertentu. (3) Korban tidak memprovokasi. (4) Perilaku bullying terjadi dalam kelompok- kelompok sosial. (5) Pelaku bullying lebih kuat daripada korban baik secara ekonomi, fisik, dan mental.

Selain definisi bullying di atas, beberapa peneliti juga telah mendefinisikan bullying berdasarkan hubungan pelaku bully dan korban. Sebagai tambahan, Salmivalli (1996) mengklasifikasi dalam beberapa kategori: (1) Ringleaders, Siswa yang berinisiatif melakukan bullying. (2) Assistant, Siswa lain yang membantu saat bullying terjadi. (3) Reinforcer, Siswa yang ikut memberi semangat kepada pelaku bullying dengan cara menertawai korban. (4) Bystander, Siswa yang berada sekitar lokasi, mengetahui terjadinya bullying tetapi tidak terlibat dan tidak bertindak apapun. (5) Defender, siswa yang membantu korban bullying.

Dampak Bullying

Masalah bullying tidak hanya sekedar berdampak pada masalah emosional tetapi juga sudah dikatakan merusak tatanan nilai-nilai sosial sehingga semua yang terlibat didalamnya harus serius dan tidak mengabaikan baik perlakuan maupun dampaknya. Dalam banyak kasus, korban yang tidak bertahan, tidak beradaptasi dengan cepat bisa berkibat fatal. Dalam beberapa kasus, korban memutuskan untuk bunuh diri dan korban yang lain menanggung cacat seumur hidup.

Rigby (1996) menyimpulkan bahwa sangat penting untuk melihat kasus bullying dan juga dampak yang diakibatkannya. Meskipun dalam banyak kejadian, banyak juga siswa yang mendapatkan perlakuan bullying di sekolahnya tetapi tidak terpengaruh secara fisik dan psikologis. Berikut ini akan digambarkan beberapa dampak perlakuan bullying yang akan dirasakan oleh pelaku bullying, korban bullying, bystander, orang tua, guru dan masyarakat.

DAMPAK TERHADAP PELAKU BULLYING. Dampak yang akan dirasakan oleh pelaku apabila perilakunya tidak dihentikan, maka pelaku akan terbiasa dengan kelakuannya dan mengganggap perilaku bullying sebagai suatu hal yang wajar. Ketika pelaku berada dalam konteks masyarakat dimana bullying tidak mendapatkan toleransi maka pelaku bullying akan dianggap sebagai pelaku kriminal yang akan berujung pada penahanan atau penjara. 
Penelitian yang dilakuan oleh Olweus (1993) menyebutkan bahwa pelaku bullying lebih banyak melakukan kelakuan anti sosial seperti perkelahian, pencurian, mabuk dan bolos. Senada dengan hasil penelitian di atas, bahwa dampak yang dirasakan juga oleh pelaku bullying yaitu hilangnya harga diri ketika melakukan kesalahan dan pelanggaran sekolah. Hal ini diperkuat dengan hasil penelitian yang menyimpulkan bahwa siswa yang terlibat pelaku bullying akan mempunyai masalah dengan harga diri.

Beberapa kejadian kriminal yang sering terjadi di masyarakat mendapatkan penguatan dan gaya hidup perilaku bullying di sekolah. Rigby (1996) menyimpulkan bahwa perilaku seperti pencurian dan sering membuat onar adalah beberapa dampak dari perilaku bullying yang sebelumnya pernah dilakukan di sekolah. Dampak lain yang akan dirasakan oleh pelaku adalah tingkat depresi yang tinggi yang muncul karena perasaan bersalah karena pernah melakukan bullying.

DAMPAK FISIK TERHADAP KORBAN. Lingkungan belajar yang kondusif dan aman adalah lingkungan belajar yang diinginkan oleh siswa, guru, orang tua siswa, sekolah dan masyarakat. Terciptanya kondisi yang kondusif ini merupakan kewajiban semua pihak termasuk di dalamnya mengetahui aspek- aspek yang membuat sekolah tidak aman bagi siswa termasuk tidak ada atau minim perlakuan bullying di dalam lingkungan belajar tersebut.

Respon yang dimunculkan siswa yang menjadi korban bullying dapat berdampak lama dan sangat tergantung terhadap daya tahan siswa dalam menghadapi masalah dan respon yang diperlihatkan siswa sangat beragam termasuk menghindari dan tidak mengerjakan tugas sekolah, perubahan perilaku, tingkat kehadiran menurun, depresi, harga diri dan percobaan bunuh diri.

Menurut Rigby (1997) siswa yang berpotensi kurang kehadiran dan perubahan perilaku terjadi pada siswa berusia maksimal 14 tahun. Dampak bullying selanjutnya karena bullying seperti kecemasan, stress, sakit perut dan panik. Selanjutnya dari 330.676 siswa yang pernah menjadi korban bullying disebutkan bahwa di Victoria Australia terdapat 78.643 siswa yang berfikir untuk tinggal di rumah dan sekitar $20 \%$ siswa yang tidak hadir kesekolah karena bullying atau sekitar 15.480 siswa. Perlakuan bullying adalah salah satu faktor yang menjadi alasan siswa untuk tidak hadir ke sekolah. Hal ini bisa berdampak kepada kesuksesan dan prestasi siswa yang menurun. Dalam situasi tingkat kehadiran yang lebih fatal, maka akan berdampak terhadap tingkat kelulusan siswa dalam suatu sekolah. Bullying merupakan masalah serius yang yang berpengaruh juga terhadap kualitas hidup dan produktifitas.

Meskipun banyak program intervensi yang dapat mengurangi dan membatasi kejadian bullying seharusnya sekolah secara khusus mempunyai program merekam dan melaporkan kejadian bullying. Program intervensi bullying harus dikembangkan lebih luas di sekolah yang mempunyai tingkat kehadiran siswa yang rendah karena masalah bullying. Sehingga, pihak sekolah harus lebih serius memperhatikan dan memeriksa daftar hadir siswa tiap kelas untuk menginvestigasi masalah tingkat kehadiran siswa dan penyebabnya.

Lebih lanjut, Garret (2003), menyebutkan dampak bullying terhadap korban seperti tingkat stress dan kecemasan yang tinggi, sering menderita sakit seperti flu, batuk dan infeksi tenggorokan Sakit pada pergelangan tanpa penyebab yang jelas, sakit kepala dan migrain, kelelahan dan Kepenatan Susah tidur, mimpi buruk, lebih cepat bangun pagi, kurang konsentrasi, pelupa, berkeringat, gemetar, dan sering panik.

DAMPAK PSIKOLOGIS TERHADAP KORBAN. Rigby (1996) menyatakan bahwa dampak yang paling umum pada bullying akan mengurangi harga diri anak dan dampak psikologis ini dapat berlangsung sampai anak menjadi dewasa. Beberapa gejala psikologis yang disebutkan 
oleh Garrett (2003) antara lain: Memperlihatkan penurunan kemampuan intelektual yang dapat dilihat dari menurunnya nilai dan prestasi yang didapatkan di sekolah sebagai akibat dari stress yang ,perkembangan sosial dan personal juga turut dipengaruhi, takut ke tempat yang tidak atau kurang diawasi di sekolah, rasa takut ini berdampak kepada absensi dan ingin meninggalkan sekolah, kehilangan atau gagal dalam mengembangkan potensi diri, merasa terisolasi, dan depresi serta malas bergabung dalam kegiatan sosial.

DAMPAK TERHADAP BYSTANDER. Bystander sering mengabaikan atau tidak memperdulikan perilaku bullying yang mereka lihat dengan berbagai alasan. Salah satu alasannya karena tidak ingin merusak hubungan baik dengan pelaku bullying itu sendiri. Oleh karena itu dibutuhkan keterampilan interaksi sosial dari bystander untuk menyelesaikan suatu konflik dan memberikan suatu solusi untuk menyelesaikan masalah bullying.

Kenyataan di lapangan dimana bystander tidak melakukan intervensi karena adanya perasaan segan yang akan membatasi kemampuan bystander dalam berkomunikasi, negosiasi dan berkompromi yang merupakan tiga hal penting dalam menyelesaikan suatu masalah dan konflik.

Menurut Pepler (1997) dalam laporan penelitian tentang dampak bullying terhadap bystander tercatat bahwa sekitar $85 \%$ perilaku bullying terjadi dalam kelompok sebaya, sedangkan $83 \%$ siswa yang melihat perilaku itu merasa tidak nyaman. Siswa yang melihat perilaku bullying tidak hanya merasa tidak nyaman tetapi juga merasa bersalah karena tidak dapat melakukan bantuan apapun terhadap korban.

DAMPAK TERHADAP GURU. Bullying tidak hanya berdampak terhadap korban dan pelaku tetapi juga berdampak terhadap suasana kondusif ruangan kelas yang berpengaruh langsung terhadap proses belajar mengajar. Sehingga, insiden yang terjadi di sekolah menjadi sinyal bagi setiap guru untuk menjamin keamanan dan kenyamanan siswa dalam belajar dan berinteraksi.

Dampak terhadap guru bisa sebagai korban bullying di tempat kerja saat melakukan tugas. Aris (2003) menyatakan bahwa banyak guru yang menjadi korban penyerangan dari orang tua, siswa, dan atasannya. Hasil penelitian yang sama diungkapkan oleh AEU Victoria (2003) bahwa satu dari empat orang pernah mendapatkan perlakuan bullying di tempat kerja. Sekitar 12\% mengatakan pernah mendapatkan perlakuan bullying dalam 12 tahun terakhir dan $15 \%$ mendapatkan perlakuan bullying secara terus-menerus. Selanjutnya, tugas guru yang lain sebagai penjamin keamanan dan kenyamanan siswa dari insiden bullying. Guru dianggap mengabaikan dan tidak mempedulikan bilamana terjadi perilaku bullying dan tidak berusaha mengintervensi.

DAMPAK TERHADAP MASYARAKAT. Perilaku bullying juga bisa berdampak terhadap masyarakat. Siswa yang dikeluarkan dari sekolah karena perilaku yang menyimpang akan mendapatkan pengawasan yang ketat orang tuanya di rumah. Ketika kurang mendapatkan pengawasan yang ketat karena ketidakhadiran orang tua dan orang dewasa maka yang akan menjadi target selanjutnya adalah dalam lingkungan masyarakat.

Dalam banyak kasus, bullying bisa terjadi dalam konteks masyarakat dalam perjalanan ke sekolah dan pulang dari sekolah. Ketika bullying terjadi di luar sekolah, secara tidak langsung akan berhadapan dengan hukum yang berlaku di tempat itu. 


\section{T-BIP ( Target Bullting Intervention Program)}

Sebelum kita melangkah jauh membahas tentang keefektifan Program T-BIP terhadap penanganan masalah bullying di sekolah. Penulis akan menginvestiasi beberapa program intervensi bullying yang telah diimplementasikan dalam program penanganan bullying di sekolah. Smith (2004) dalam hasil kajiannya terhadap 14 hasil penelitian tentang program intervensi bullying "Whole School" bahwa mayoritas dari penelitian tersebut tidak memberikan dampak yang signifikan terhadap menurunnya angka perilaku bullying di sekolah. Berbeda dengan kajian yang dilakukan dilakukan oleh Merrell, dkk. (2008) yaitu program intervensi bullying ini sangat berpengaruh signifikan terhadap perilaku bullying yang kerap terjadi di sekolah. Secara umum, program intervensi bullying memperlihatkan hasil yang positif antara lain terhadap persepsi dan pengetahuan tentang bullying. Meskipun disimpulkan bahwa dampak program ini masih relatif kurang terhadap penanganan bullying yang terjadi.

Penelitian meta analisis yang lain dilakukan oleh Farrington dan Ttofy (2009) menyimpulkan bahwa berbagai penelitian tentang program penanganan masalah bullying memperlihatkan hasil yang memuaskan karena berdampak signifikan terhadap pengurangan kasus bullying dan beberapa kalangan menyebutkan bahwa program intrevensi bullying ini lebih banyak mengadopsi dari program Olweus Bullying Prevention Program (OBPP).

Hasil penelitian dan review terbaru terhadap program intervensi bullying disebutkan bahwa 12 program intervensi yang dilaksanakan berdampak sangat positif terhadap pengurangan perilaku bullying dan peningkatan pada "bystander" dalam mengintervensi perilaku bullying yang terjadi (Polanin dkk, 2012). Secara keseluruhan dapat disimpulkan bahwa program intervensi bullying yang terjadi di sekolah efektif dalam mengurangi perilaku bullying, dampak bullying dan juga peran aktif diluar korban dan pelaku bullying yang berada pada saat kejadian.

Program T-BIP adalah salah satu program intervensi bullying yang memberikan bantuan terhadap korban. Menurut Berry and Swearer (2003) terdiri dari beberapa sesi yaitu baseline, psikoedukasi dan umpan balik. Pada tahap baseline, siswa yang menjadi target bullying diidentifikasi melalui rekomendasi dari guru bimbingan konseling. Kemudian berbagai informasi tentang siswa tersebut dikumpul dn dianalisa untuk memastikan bahwa siswa yang bersangkutan memang tepat untuk mengikuti program tersebut.

Sebagai tahap awal, siswa yang pernah melihat, merasakan dan melakukan diberikan angket yang berkaitan dengan frekwensi, bentuk, motif dari perilaku bullying dan selanjutnya, siswa yang terlibat bullying baik pelaku atau korban akan diberikan pemahaman terhadap bullying. Selanjutnya, pihak orang tua juga diberikan angket berkaitan dengan perilaku anaknya selama mengikuti program T-BIP. Pada tahap psikoedukasi, siswa diberi kesempatan untuk berkonsultasi terhadap apapun yang terkait dengan bullying. Konseling terhadap masalah yang dihadapi diberikan kepada siswa pada tahap akhir yaitu umpan balik.

Salah satu tujuan dari T-BIP adalah membuka sesuatu yang belum terdeteksi tentang keterlibatan siswa dalam perilaku bullying melalui penilaian formal dan informal seperti diskusi dengan korban dan angket. Lebih jauh, T-BIP memberikan pengetahuan kritis terhadap bullying dengan memperlihatkan dan memberikan alternatif solusi bagaimana mengatasinya. Pengetahuan tentang bullying ini diharapkan dapat membantu siswa dalam memahami dan membedakan perbuatan bullying dan lelucon, empathi terhadap korban, paham akan dampak bullying sehingga bisa sukses dalam situasi propokatif dalam menyelesaikan masalah bullying yang terjadi. Diharapkan juga tercipta hubungan yang harmonis antara guru, siswa dan pihak orang tua karena pada sesi tertentu orang tua diminta hadir dalam memberikan informasi terkait 
perilaku siswa. Kerjasama dan hubungan ini diharapkan menjadi kolaborasi sekolah dan orang tua dalam rangka menjembatani komunikasi terhadap dukungan terbaik terhadap siswa.

\section{Setting Penelitian dan Kajian Masalah}

Penelitian melibatkan empat orang siswa sebagai responden, sedangkan, dua orang guru konseling dijadikan model sekaligus konsultan bagi siswa. Semua siswa terdaftar pada SMPN 4 Pangkajene, dan gurunya juga bertugas pada sekolah tersebut. Adapun masalah penelitian adalah sebagai berikut

1. Bagaimana program Intervensi T-BIP dalam meningkatkan perilaku anti bullying pada siswa?

2. Bagaimana persepsi siswa terhadap program intervensi bullying (T-BIP)?

\section{Model Penelitian dan pengukuran}

Model penelitian yang dilakukan yaitu metode kuantitatif, dimana metode sample yang dipakai yaitu purposive sampling yaitu merupakan korban bullying berdasarkan catatan dan laporan guru bimbingan konseling. Dalam penelitian ini empat siswa dijadikan sampel untuk mengikuti dan mengisi kuesioner yang sudah disiapkan untuk melihat program T-BIP terhadap perilaku bullying siswa, perilaku bullying siswa diukur dengan menggunakan angket Bullyig yang merupakan adaptasi dari Swearer Bully Survey (SBS). Sedangkan persepsi siswa terhadap program T-BIP juga menggunakan angket yang mengadaptasi (BIRP, Bullying Intervention Rating Profile) yang telah diterjemahkan yang terdiri dari 7 pernyataan yang memiliki lima opsi pilihan (Sangat Setuju, Setuju, Abstain, Tidak setuju dan Sangat Tidak Setuju). Angket ini memiliki tingkat keabsahan dan validitas instrumen sebanyak 0.86 .

\section{Hasil Penelitian dan Diskusi}

Investigasi apakah T-BIP menyebabkan perubahan pada siswa akan diperlihatkan pada table dibawah

Mean and Standard Deviasi Perilaku Anti Bullying Siswa

\begin{tabular}{lclll}
\hline \multicolumn{2}{l}{ Nilai Perilaku Anti-Bullying } & \multicolumn{3}{l}{ Tahap } \\
\hline \multirow{2}{*}{ Yusril } & Mean & Pra & Session & Post \\
& $S D$ & 35.00 & 34.00 & 36.13 \\
\multirow{2}{*}{ Hidayat } & Mean & 2.38 & 2.10 & 1.71 \\
& $S D$ & 31.50 & 30.33 & 34.00 \\
\multirow{2}{*}{ Putri } & Mean & 2.61 & 1.41 & 4.24 \\
& $S D$ & 29.44 & 30.83 & 30.41 \\
\multirow{2}{*}{ Ilma N } & Mean & 1.67 & 1.40 & 1.17 \\
& $S D$ & 36.33 & 40.75 & 43,8 \\
\hline
\end{tabular}

Note. $\mathrm{SD}=$ Standard Deviation

Berdasarkan data diatas, hipotesis bahwa T-BIP akan meningkatkan perilaku anti bullying. Kenyataannya, bahwa T-BIP, tidak terlalu berdampak signifikan terhadap perilaku anti 
bullying siswa. Baik Yusril dan Hidayat kurang memperlihatkan perubahan perilaku selama penelitian dan pengumpulan data berlangsung. Sedangkan Putri menunjukkan perubahan yang sangat kecil pada tiga tahap pengumpulan data dan perubahan ini tidak bertahan sampai pada pengambilan data terakhir. Selanjutnya Ilma juga memperlihatkan perubahan yang tidak signifikan terhadap perubahan perilaku. Sehingga dapat disimpulkan bahwa terdapat perubahan yang kecil pada penggunaan T-BIP pada perubahan perilaku bullying siswa dan perubahan kecil terjadi secara tidak konsisten terhadap keempat siswa.

Ada beberapa kemungkinan mengapa T-BIP tidak begitu berpengaruh pada perilaku anti bullying. Pertama, mungkin karena periode pengumpulan data yang terlalu singkat dalam penelitian ini dari tiga sesi program T-BIP dan alasan kedua pada sesi pengenalan bullying melalui "Presentasi power point" hanya memberikan garis besar tentang faktor dan dampak bullying. Kemungkinan ada faktor dan dampak lain diluar yang dipresentasikan. Menurut Fazio dan Ozlon (2007), bahwa perilaku manusia terdiri dari kompenen kognitif dan afektif sehingga sangat memungkinkan dimana bagian yang ditanyakan dalam angket tidak mewakili perilaku bullying.

Penelitian yang dilakukan oleh Horne dkk (2012) tentang program intervensi bullying sangat efektif dalam mengurangi frekwensi bullying dan meningkatkan pengetahuan dan kesadaran di sekolah. Dalam hal ini, guru dan staf diharapkan menjadi model yang baik dan melibatkan perilaku sosial.

Selanjutnya persepsi siswa terhadap penggunaaan T-BIP diukur dengan menggunakan angket BIRP dengan rentang nilai 7-35, dimana partisipasi siswa tercatat dalam rentang 33 dan angka persentase sebanyak $94 \%$ seperti terlihat pada grafik dibawah.

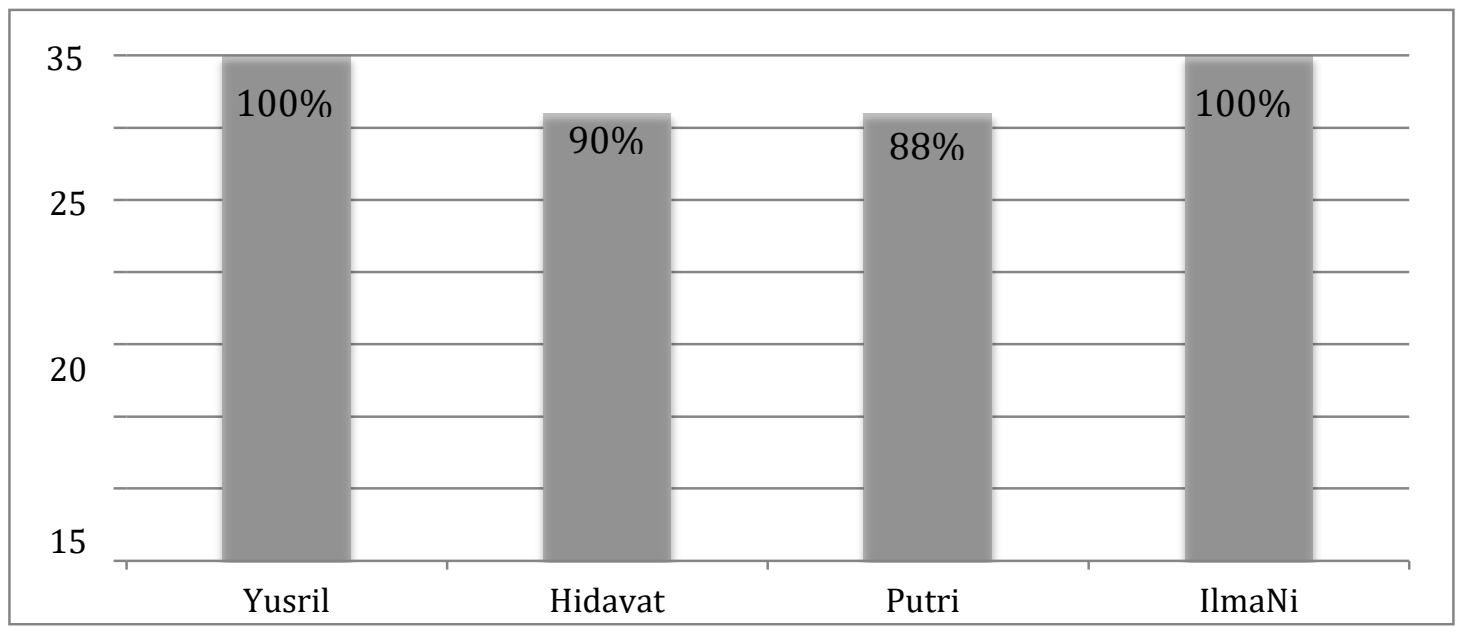

Tabel, Mean, Standard Deviasi, dan Persentasi Penerimaan terhadap T-BIP

\begin{tabular}{llll}
\hline Tingkat Penerimaan Perlakuan & & & \\
\hline \multirow{2}{*}{ Siswa } & Mean & SD & Persentase \\
& 33 & 1.25 & $94 \%$ \\
\hline
\end{tabular}

$\mathrm{SD}=$ Standard Deviation 
Berdasarkan nilai diatas kita bisa mengambil kesimpulan bahwa tingginya partisipasi ini semakin banyak laporan yang masuk mengenai kasus bullying yang terjadi. Meskipun ini bersifat spekulasi karena dalam penelitian ini tidak diketahui motif dari siswa dalam melaporkan kasus bullying.

Menurut Olweus (1993) bahwa partisispasi siswa dalam program intervensi bullying akan meningkatkan kesadaran terhadap masalah yang dihadapi. Dalam penelitian konsultasi ssiswa dengan guru konseling sangat penting untuk mendapatkan informasi yang valid dari siswa tentang masalah bullying. Keuntungan lain dari intervensi bullying yang dilakukan disekolah guru dan staf sekolah juga belajar dan dapat meningkatkan pengetahuannya melaui tentang bullying pada sesi pelatihan.

\section{Kesimpulan}

Peningkatan perhatian tentang bullying juga seiring dengan perhatian terhadap intervensi bullying. Meskipun dalam penelitian ini program T-BIP dalam penelitian ini kurang berdampak pada siswa khususnya perubahan peningkatan anti bullying dan pengurangan perilaku bullying tetapi program intervensi sangat berterima oleh siswa di sekolah.

Kajian mengenai intervensi bullying sangat berkembang dan banyak sekali modifikasi program yang diharapkan sesuai dengan kondisi sekolah dan juga pertimbangan efektifas biaya dan waktu. Meskipun terdapat keterbatasan, tetapi program T-BIP ini cukup unik dan juga cukup berpotensi dalam hal pengurangan perilaku bullying di sekolah dan meningkatkan kesadaran siswa akan dampak yang ditimbulkan oleh intervensi ini. Salah satu kekuatan dalam penelitian ini yaitu partisipasi siswa yang sangat tinggi yang diharapkan akan dapat mengubah perilaku bullying siswa meskipun secara statistik perubahan perilaku siswa terhadap bullying tidak konsisten dalam beberapa tahap.

\section{Referensi}

Aris.(2003). The perception of bully victims and parents social support. Journal of Educational.35, 20-34

Besag, V. E. (1989). Bullies and victims in schools. Britain: Open University Press.

Björkqvist, K., Ekman, K., \& Lagerspetz, K. (1982). Bullies and their victims: Their ego picture, ideal ego picture and normal ego picture. Scandinavian Journal of Psychology, $23,307-313$.

Fazio, R. H., \& Olson, M. A. (2007). Attitudes: Foundations, functions, and consequences. In M. A. Hogg \& J. Cooper (Eds.), The sage handbook of social psychology (pp. 123-145). London: Sage Publications.

Horne, A. M., Nitza, A., Dobias, B. F., Jolliff, D. L., Raczynski, K. A., \& Voors. W. (2012). Empowering teen peers to prevent bullying: The Bully Busters Program for high school. Champaign, IL: Research Press.

Konrad Lorenz.(1968). Bullying and Harrassment in Workplace.CRC Press,London.

Nansel, T., Overpeck, M., Pilla, R., Ruan, W., Simons-Morton, B., \& Scheidt, P. (2001). Bullying behaviors among US youth: Prevalence and Association with Psychosocial Adjustment. Journal of the American Medical Association, 285, 2094-2100. doi:10.1001/jama.285.16.2094 
Olweus, D. (1993). Bullying at school: what we know and what we can do. Oxford, UK:

Blackwell Publishing

Olweus, D. (1994). Annotation, bullying at school: basic facts and effects of a school-based intervention program. Journal of Child Psychology and Psychiatry, 35(7), 1171-1190

Rigby, K., and Cox, I. K. (1996). The contributions of bullying and low self-esteem to acts of delinquency among Australian teenagers. Personality and Individual Differences 21, 4, pp 609-612.

Rigby, K. (1997). Bullying in schools: And what to do about it. Melbourne: Australian Council Educational Research.

Salmivalli, C., Lagerspetz, K.M.J., Björkqvist, K., Österman, K., \& Kaukiainen, A. (1996). Bullying as a group process: Participant roles and their relations to social status in the group. Aggressive Behavior. 22 , 1-15. 